\title{
EKSTRAK DAUN MANGGA (Mangifera indica L.) SEBAGAI ANTIJAMUR TERHADAP JAMUR Candida albicans DAN IDENTIFIKASI GOLONGAN SENYAWANYA
}

\author{
Dian Riana Ningsih*, Zusfahair, Diyu Mantari \\ Jurusan Kimia FMIPA \\ Universitas Jenderal Soedirman \\ *email: deeyan_bik@yahoo.com
}

Received 22 Pebuari 2017

Accepted 9 April 2017

\begin{abstract}
Abstrak
Candida albicans adalah salah satu jamur yang dapat menyebabkan infeksi candidiasis. Salah satu bahan obat alami dari ekstrak tanaman yang berpotensi sebagai antijamur adalah ekstrak daun mangga (Mangifera indica L.). Penelitian ini bertujuan untuk mengetahui aktivitas antijamur daun mangga terhadap $C$. albicans, penentuan konsentrasi hambat tumbuh minimum (KHTM) dan mengidentifikasi golongan senyawa kimia dari ekstrak tersebut yang berpotensi sebagai antijamur. Daun mangga diekstraksi secara maserasi menggunakan pelarut metanol. Ekstrak metanol daun mangga yang dihasilkan dilakukan uji aktivitas antijamur terhadap $C$. albicans dengan menggunakan metode difusi. Setelah diketahui aktivitasnya, ekstrak metanol daun mangga kemudian ditentukan konsentrasi hambat tumbuh minimum (KHTM) dan diuji kandungan metabolit sekundernya dengan uji fitokimia. Hasil ekstraksi daun mangga dengan pelarut metanol menghasilkan ekstrak metanol dengan rendemen $10,55 \%$ (b/b) dan menghasilkan aktivitas antijamur dengan zona hambat terbesar pada konsentrasi 1000 ppm dengan zona hambat 8,12 mm. KHTM ekstrak metanol daun mangga terhadap $C$. albicans yaitu pada konsentrasi $65 \mathrm{ppm}$ dengan zona hambat sebesar 0,64 mm. Berdasarkan hasil uji fitokimia ekstrak metanol daun mangga menunjukkan adanya senyawa golongan alkaloid, flavonoid, stereoid, polifenol, tanin, dan saponin.
\end{abstract}

Kata kunci : Antijamur, Candida albicans, KHTM, Mangifera indica L.

\begin{abstract}
Candida albicans is one of the fungal which causes infection. The treatment of fungal infection topical medicinesemi-synthetic can create resistance. Therefore, it is necessary to find natural medicine from potential herbal extract as antifungal to overcome the problem. Mango leaves is one of the potential herbal. The research was aimed to determine antifungalsmango leaves activities to $\mathrm{C}$. albicans, to determine the minimum inhibitory concentration (MIC) and identifythe active chemical compoundsgroupof the extract as antifungal.Mango leaves were extracted by maceration using methanol. Methanol extract was tested for its antifungal activity toward C. albicans showed by highest antifungals activity then determined Minimum inhibitory concentration (MIC), tested secondary metabolite compounds content using phytochemical test.The extraction result of mango leaves with methanol was resulted the methanol extract with a yield of $10,55 \%(\mathrm{w} / \mathrm{w})$ and
\end{abstract}


the methanol extract showed an antifungals activities with the largest inhibition zone at a concentration of 1000 ppmwith inhibition zone of 8,12 mm.Minimum inhibitory concentration (MIC) of the mango's methanol extract toward C. albicanswas on $65 \mathrm{ppm}$ with inhibitory zone of $0.64 \mathrm{~mm}$. Based on phytochemical test result analysis of it extract showed alkaloid, flavonoid, stereoid, polyphenol, tannins and saponin compound catagories.

Keywords : Antifungals, Candida albicans, Mangifera indica L., MIC

\section{Pendahuluan}

Infeksi merupakan penyakit yang mudah ditemukan di daerah tropis seperti Indonesia. Penyebab penyakit infeksi yang mudah ditemukan diantaranya adalah infeksi karena jamur. Jamur yang banyak menyebabkan infeksi adalah jamur Candida. Infeksi yang disebabkan oleh Candida dikenal dengan Candidiasis. Candidiasis adalah suatu penyakit jamur yang bersifat akut dan sub akut yang dapat mengenai mulut, vagina, kulit, kuku, paruparu dan saluran pencernaan dan disebabkan oleh spesies Candida, biasanya oleh Candida albicans (C. albicans). Jamur $C$. albicans merupakan salah satu jamur patogen pada manusia. Penyakit ini ditemukan di seluruh dunia dan dapat menyerang semua umur, baik laki-laki maupun perempuan (Jawetz et al., 2005).

Obat topikal yang selama ini digunakan untuk mengobati candidiasis kulit meliputi nistatin, klotrimazol, mikonazol, ketokonazol dan azol-azol lainnya. Akan tetapi obat-obat antijamur tersebut memiliki keterbatasan, seperti efek samping yang berat, spektrum antijamur yang sempit, penetrasi yang buruk pada jaringan tertentu, dan munculnya jamur yang resisten (Jawetz et al., 2005). Untuk mengatasi efek negatif yang ditimbulkan oleh obat antijamur sintetis tersebut, maka perlu dilakukan eksplorasi terhadap obat antijamur yang bersifat alami. Salah satu sumber yang dapat dijadikan sebagai obat antijamur alami adalah tanaman. Tanaman seringkali digunakan sebagai obat untuk penyembuhan suatu penyakit karena tidak memiliki efek samping. Senyawa antijamur yang berasal dari tanaman sebagian besar diketahui merupakan metabolit sekunder tanaman, terutama golongan fenolik dan terpen dalam minyak atsiri (Nychas dan Tassou, 2000).

Salah satu tanaman yang berpotensi sebagai tanaman obat adalah tanaman mangga. Tanaman mangga (Mangifera indica L.) merupakan tanaman yang berpotensi sebagai obat herbal karena mengandung senyawa metabolit sekunder. Penelitian-penelitian yang telah dilakukan terhadap tanaman mangga yaitu daun mangga sebagai antioksidan, antimikroba, dan antitumor. Selain flavonoid tanaman mangga juga mengandung saponin, tanin galat, tanin katekat, kuinon dan steroid atau tripenoid (Widijanti dan Bernard, 2007). Pada penelitian ini ekstrak metanol daun mangga digunakan sebagai antijamur. Mangga merupakan tanaman yang melimpah dan bagian daun tanaman tersebut kurang dimanfaatkan oleh masyarakat. Oleh karena itu, penelitian tentang daun tanaman mangga ini sangat menarik untuk dilakukan. Kemampuan ekstrak daun mangga (Mangifera indica L.) sebagai antijamur perlu untuk diteliti. Dalam penelitian ini, akan dilakukan ekstraksi secara maserasi terhadap daun mangga dengan pelarut metanol. Ekstrak metanol yang diperoleh dilakukan uji aktivitas antijamurnya terhadap jamur $C$. albicans, penentuan Konsentrasi Hambat Tumbuh Minimum (KHTM) serta diidentifikasi.

\section{Metode Penelitian}

Alat dan Bahan

Alat yang digunakan dalam penelitian ini adalah blender, oven, autoklaf, 
timbangan analitik, waterbath, filler, pipet ukur, hot plate, mikropipet, drugalsky, inkubator, tabung reaksi, rak tabung reaksi, cawan Petri, kapas, kassa, wrapping, sarung tangan, derigen, botol semprot, label, gunting, cutter, kain lap, lampu spirtus, jarum ose, lemari pendingin dan spektrofotometer Thermo Scientific Genesys 20.

Bahan-bahan yang digunakan dalam penelitian ini adalah daun mangga yang diambil dari Kampus MIPA Kelurahan Karangwangkal Universitas Jenderal Soedirman Purwokerto, metanol, jamur Candida albicans yang diperoleh dari koleksi Laboratorium Mikrobiologi Fakultas Biologi Universitas Jenderal Soedirman, alkohol 70\%, pepton, glukosa, aquades, media Potato Dextrose Agar (PDA) kertas saring, tissue, $\mathrm{I}_{2}, \mathrm{KOH}, \mathrm{HCl}$, $\mathrm{HCl}$ pekat, serbuk $\mathrm{Mg}$, pereaksi Mayer, pereaksi $\mathrm{FeCl}_{3}$, pereaksi LibermanBurchard, dan ketokonazol.

\section{Prosedur Penelitian}

\section{Ekstraksi (Ningsih, et al., 2014)}

Sebanyak kurang lebih 100 gram serbuk daun mangga diekstraksi secara maserasi dengan menggunakan $350 \mathrm{~mL}$ metanol sampai semua serbuk terendam dan diaduk lalu ditutup dan disimpan selama tiga hari. Pengadukan dilakukan kurang lebih sebanyak tiga kali sehari. Selanjutnya dilakukan penyaringan sehingga didapat filtrat dan residu. Residu yang dihasilkan kemudian dimaserasi dengan penambahan $50 \mathrm{~mL}$ metanol selama 3 hari dan dilakukan penyaringan setiap hari. Semua filtrat yang dihasilkan disatukan menjadi satu dalam satu wadah sebagai filtrat ekstrak metanol. Kemudian filtrat tersebut dipekatkan dengan vacuum rotary evaporator hingga didapatkan ekstrak yang kental kemudian ditimbang.

\section{Uji aktivitas antijamur (Sari, 2010)}

Pengujian aktivitas dilakukan dengan metode difusi agar. Pada pengujian ini semua bahan dan alat yang akan digunakan harus dalam keadaan steril. Prosedur pengujian aktivitas adalah sebagai berikut: jamur $C$. albicans ditumbuhkan dalam medium Sabauraud Dextrose Broth (SDB) cair selama 24 jam. Suspensi isolat ini diukur dengan spektrofotometer pada $\lambda$ $600 \mathrm{~nm}$ hingga diperoleh nilai transmitan $25 \%$, bila belum mencapai $25 \%$ dilakukan pengenceran bertingkat dengan menggunakan aquades. Kemudian Sebanyak $50 \mu \mathrm{L}$ kultur $C$. albicans cair disebarkan secara merata di atas medium Potato Dextrose Agar (PDA) padat. Setelah media PDA memadat dibuat tiga lubang dengan menggunakan cork borer dan diberikan ekstrak daun mangga sebanyak $50 \mu \mathrm{L}$ pada tiap lubang dengan konsentrasi yang digunakan untuk pengujian daya hambat adalah $1000 \mathrm{ppm}$. Masing-masing kultur diinkubasi selama 1x24 jam pada suhu $37^{\circ} \mathrm{C}$, perlakuannya duplo. Kemudian diukur daerah hambat (daerah bening di sekitar lubang) dari masing-masing $C$. albicans untuk setiap ekstrak daun mangga. Kontrol negatif adalah aquades dan kontrol positif adalah ketokonazol dengan konsentrasi 1000 ppm. Adanya daerah bening di sekitar lubang menunjukkan bahwa senyawa tersebut memiliki aktivitas anticandidiasis. Hasil yang menunjukkan zona hambat terbesar dari ekstrak tersebut akan digunakan pada uji selanjutnya.

\section{Penentuan konsentrasi hambat tumbuh minimum (KHTM)}

Setelah diketahui bahwa ekstrak daun mangga mempunyai aktivitas antijamur, selanjutnya ditentukan uji Konsentrasi Hambat Tumbuh Minimum (KHTM) pada ekstrak daun mangga terhadap jamur uji. Metode yang digunakan sama seperti metode yang dipakai dalam pengujian aktivitas antijamur ekstrak metanol daun mangga dengan melakukan variasi konsentrasi sampel. Pengujian ekstrak metanol daun mangga menggunakan konsentrasi $1000 ; 500 ; 250 ; 125 ; 65 ; 30$; 15; 10; 5; dan 1 ppm. Masing-masing konsentrasi sebanyak $50 \mu \mathrm{L}$ diuji dengan memasukkan ke lubang media PDA yang 
telah diinokulasi dengan jamur. Setelah itu diinkubasi pada suhu $37{ }^{\circ} \mathrm{C}$ selama $1 \times 24$ jam. Kontrol negatif adalah aquades dan kontrol positif adalah ketokonazol dengan konsentrasi 1000 ppm. Konsentrasi Hambat Tumbuh Minimum (KHTM) antijamurnya diperoleh dengan mengukur daerah bening di sekeliling lubang sampel dengan menggunakan jangka sorong dari masing-masing ekstrak daun mangga.

Identifikasi senyawa kimia ekstrak daun mangga (Harborne, 1987)

Uji senyawa alkaloid

Sebanyak $2 \mathrm{~mL}$ sampel dilarutkan dalam $2 \mathrm{~mL} \mathrm{HCl} \mathrm{2 \% ,} \mathrm{dipanaskan} 5$ menit dan disaring. Filtrat yang diperoleh ditetesi dengan pereaksi Mayer sebanyak 2-3 tetes. Adanya senyawa alkaloid ditujukkan dengan terbentuknya endapan putih.

\section{Uji senyawa flavonoid}

Sebanyak $2 \mathrm{~mL}$ sampel dilarutkan dalam $2 \mathrm{~mL}$ metanol, kemudian ditambahkan serbuk $\mathrm{Mg}$ dan $\mathrm{HCl}$ pekat sebanyak 5 tetes. Adanya senyawa flavanoid ditunjukkan dengan terbentuknya warna merah atau jingga.

\section{Uji senyawa saponin}

Sebanyak $2 \mathrm{~mL}$ sampel dilarutkan dalam aquades pada tabung reaksi ditambah 10 tetes $\mathrm{KOH}$ dan dipanaskan dalam penangas air $50{ }^{\circ} \mathrm{C}$ selama 5 menit, dikocok selama 15 menit. Jika terbentuk busa mantap setinggi $1 \mathrm{~cm}$ dan tetap stabil selama 15 menit menunjukkan adanya senyawa saponin.

\section{Uji senyawa stereoid dan terpenoid}

Sebanyak $2 \mathrm{~mL}$ sampel ditambah dengan pereaksi Liberman-Burchard 1 $\mathrm{mL}$. Adanya senyawa terpenoid ditujukkan dengan terbentuknya warna biru tua atau hijau kehitaman.

\section{Uji senyawa polifenol}

Sebanyak $2 \mathrm{~mL}$ sampel dilarutkan dalam aquades $10 \mathrm{~mL}$, dipanaskan 5 menit dan disaring. Filtrat yang terbentuk ditambahkan dtambahkan 4-5 tetes $\mathrm{FeCl}_{3}$ $5 \%(\mathrm{~b} / \mathrm{v})$. Adanya fenol ditujukkan dengan terbentuknya warna biru tua atau hijau kehitaman.

\section{Uji senyawa tanin}

Sebanyak $2 \mathrm{~mL}$ sampel ditambah dengan pereaksi $\mathrm{FeCl}_{3}$. Adanya senyawa tanin ditunjukkan dengan terbentuknya warna biru tua atau hijau kehitaman.

\section{Hasil dan Pembahasan}

\section{Uji Aktivitas Antijamur}

Pekerjaan pertama yang dilakukan dalam penelitian ini adalah mengeringkan sampel daun mangga tanpa terkena sinar matahari secara langsung selama 14 hari. Air dalam sampel dapat menyebabkan terjadinya reaksi enzimatis yang mengakibatkan rusaknya sampel karena susunan senyawa yang terdapat dalam daun tersebut telah berubah (Ningsih et al.,.. 2016). Sampel selanjutnya dibuat serbuk dan dimaserasi. Menurut Nobre dan Moura (2005) membandingkan kadar flavonoid Momordica charantia L. menggunakan metode maserasi dan perkolasi, hasilnya bahwa metode maserasi lebih baik.

Pelarut yang digunakan selama maserasi adalah metanol. Metanol dipilih sebagai pelarut karena memiliki kepolaran yang tinggi sehingga mampu melarutkan sebagian besar senyawa yang ada dalam simplisia sehingga diharapkan senyawasenyawa yang bersifat antijamur dapat terekstrak di dalam metanol. Pelarut dengan kepolaran rendah, lebih sedikit menarik ekstrak aktif dibandingkan dengan campuran etanol dan metanol atau metanol saja (Ismail, et al., 2004). Selain itu, karena diketahui bahwa senyawa dari daun mangga adalah mangiferin yang bersifat polar. Berdasarkan konsep polarisasi, semakin polar suatu senyawa semakin mudah senyawa itu larut dalam pelarut yang polar juga. (Pohan, et al., 2013).

Filtrat yang didapat kemudian dipisahkan dengan pelarutnya 
menggunakan alat vacuum rotary evaporator. Suhu yang digunakan adalah $65{ }^{0} \mathrm{C}$, karena disesuaikan dengan titik didih metanol yakni sebesar $64,7{ }^{0} \mathrm{C}$ dengan laju putaran sebesar 55 rpm. Dari ekstraksi maserasi dapat dihasilkan ekstrak metanol kental yang berwarna hijau kehitaman sebanyak 10,55 g dengan rendemen $10,55 \%(b / b)$. Filtrate yang diperoleh diuji aktivitas antijamur.

Uji aktivitas antijamur ini menggunakan konsentrasi 1000 ppm sebagai uji pendahuluan. Uji aktivitas antijamur ini juga dilakukan terhadap kontrol positif ketokonazol dan kotrol negatif aquades. Ketokonazol digunakan sebagai kontrol positif dikarenakan ketokonazol sudah terbukti bersifat antijamur terhadap C.albicans. Hasil uji aktivitas ekstrak daun mangga dan ketokonazol dapat dilihat pada Gambar 1.

Berdasarkan hasil penelitian, menunjukkan bahwa ekstrak daun mangga memiliki aktivitas antijamur terhadap $C$. albicans. Aktivitas antijamur pada konsentrasi 1000 ppm yakni sebesar 8,12 $\mathrm{mm}$. Kontrol positif ketokonazol dengan konsentrasi 1000 ppm memiliki aktivitas sebesar 8,30 mm dan aquades sebagai kontrol negatif menunjukkan nilai negatif, yakni $0 \mathrm{~mm}$.

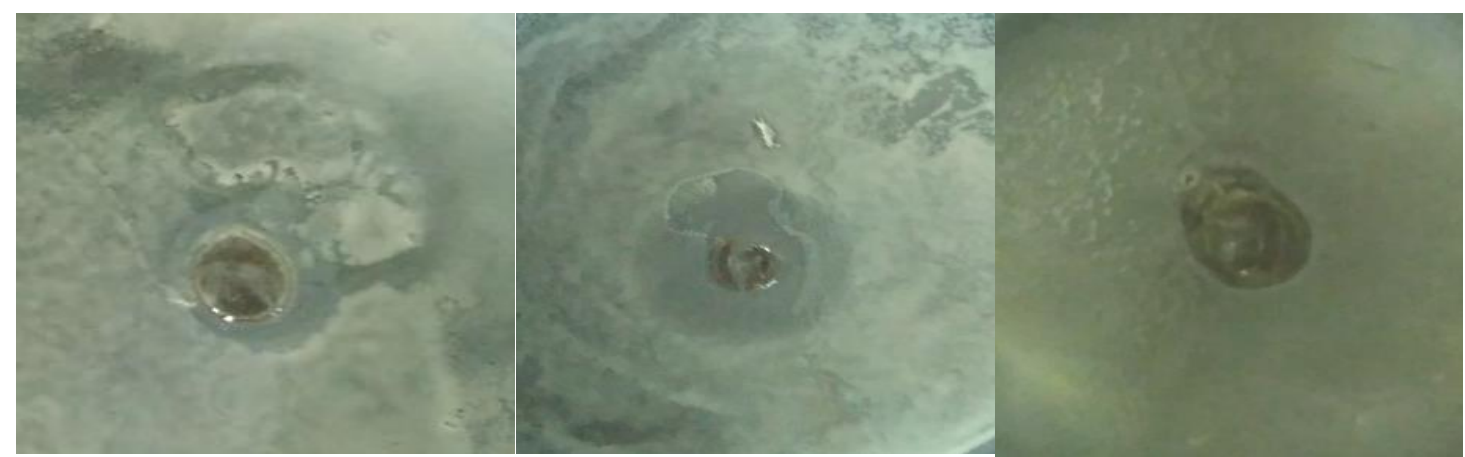

(a) (b)

Gambar 1. (a) Uji aktivitas antijamur ekstrak daun mangga (b) ketokonazol (c) aquades

Penentuan Konsentrasi Hambat Tumbuh Minimum Ekstrak Metanol Daun Mangga Konsentrasi Hambat Tumbuh Minimum adalah konsentrasi terendah antijamur yang masih mampu menghambat pertumbuhan jamur. Penentuan KHTM ini dilakukan untuk mengetahui konsentrasi minimum sampel yang dapat menghambat $C$. albicans. Antijamur dikatakan mempunyai aktivitas yang tinggi bila KHTM terjadi pada kadar sampel yang rendah tetapi mempunyai daya hambat yang besar. Grafik penentuan KHTM dari ekstrak metanol daun mangga terhadap C. albicans dapat dilihat pada Gambar 2. Penentuan KHTM dilakukan dengan menguji sederetan konsentrasi sampel yang dibuat dengan cara pengenceran. Konsentrasi ekstrak metanol daun mangga yang digunakan dalam penentuan KHTM berkisar antara 1-1000 ppm.

Berdasarkan hasil penelitian seperti yang disajikan pada Gambar 2 menunjukkan bahwa aktivitas antijamur ekstrak metanol daun mangga menurun seiring dengan menurunnya konsentrasi. Hal ini sesuai dengan pernyataan Pelchar dan Chan (1988), bahwa semakin tinggi konsentrasi suatu bahan antimikroba maka aktivitas antimikrobanya semakin besar pula.

Ekstrak metanol dengan konsentrasi terkecil yaitu konsentrasi 65 ppm masih dapat menghambat pertumbuhan jamur $C$. albicansyakni sebesar $0,64 \mathrm{~mm}$ sedangkan pada konsentrasi 30 ppm hingga 1 ppm sudah tidak dapat menghambat pertumbuhan jamur $C$. albicans. 
- Series1, 1000,

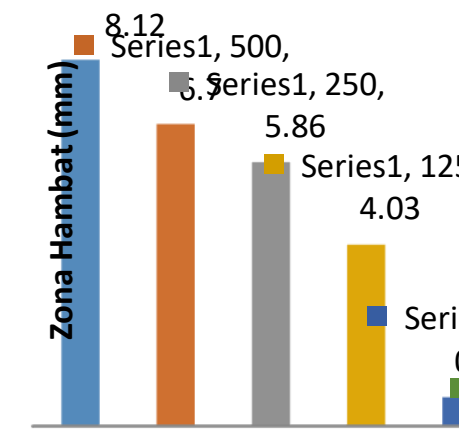

Series1, 65, 0.64

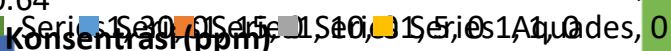

Gambar 2 Grafik Konsentrasi Hambat Tumbuh Minimum (KHTM) Ekstrak Metanol Daun Mangga terhadap C. Albicans

Identifikasi Senyawa Kimia Ekstrak Metanol Daun Mangga

Uji fitokimia digunakan untuk mengetahui adanya golongan senyawa metabolit sekunder seperti alkaloid, flavonoid, stereoid, polifenol, tanin dan saponin dalam daun mangga. Hasil fiktokimia ekstrak metanol daun mangga dapat dilihat pada Tabel 1. Penghambatan ekstrak metanol daun mangga terhadap $C$. albicans disebabkan oleh adanya kandungan zat aktif yang diduga berperan sebagai zat antijamur. Senyawa alkaloid,
Series1, 1000

Ketokonazol,

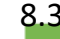

Tabel 1. Hasil Identifikasi Senyawa Kimia Ekstrak Metanol Daun Mangga

\begin{tabular}{ccc}
\hline Senyawa & Warna & Hasil \\
\hline Flavonoid & Merah / jingga & Positif (+) \\
Alkaloid & Endapan putih & Positif $(+)$ \\
Steroid & Hijau tua & Positif $(+)$ \\
Terpenoid & Hijau tua & Negatif $(-)$ \\
Polifenol & Hijau Kebiruan (+) & Positif $(+)$ \\
Tanin & Hijau kebiruan $(+++)$ & Positif $(+)$ \\
Saponin & Busa yang stabil $\pm 1,5 \mathrm{~cm}$ & Positif $(+)$ \\
\hline
\end{tabular}

Senyawa antijamur mempunyai berbagai mekanisme penghambatan terhadap sel jamur. Djunaedy (2008) menyatakan bahwa senyawa antijamur memiliki mekanisme kerja dengan cara menetralisasi enzim yang terkait dalam invasi jamur, merusak membran sel jamur, menghambat sistem enzim jamur sehingga mengganggu terbentuknya ujung hifa dan mempengaruhi sintesis asam nukleat dan protein. Mustikasari dan Ariyani (2010) flavonoid, stereoid, polifenol dan tanin memiliki aktivitas sebagai antijamur. Adegoke dan Bukola (2009) juga menyatakan bahwa ekstrak metanol dan air tumbuhan Lasienthera africanum menghambat aktivitas Escherichia coli, Salmonella typhi, Klebsiella pneumonia dan Staphylococcus aureus. Menurut Sabir (2005), senyawa flavonoid yang terdapat pada propolis Trigona sp mampu menghambat pertumbuhan Streptococcus mutans secara in vitro. menyatakan bahwa senyawa alkaloid memiliki aktivitas sebagai antimikroba dengan merusak dinding sel mikroba. Menurut Zhu, et al. (2000), steroid yang di isolasi dari daun damar dapat beracun, toksik bagi mikroba dan memiliki efek antijamur sehingga dapat digunakan dalam bidang pengobatan. Masing-masing senyawa metabolit sekunder memiliki cara kerja yang berbeda-beda (Fitriani et al., 2012). 


\section{Kesimpulan}

Berdasarkan hasil penelitian ini diperoleh simpulan sebagai berikut : Ekstrak metanol daun mangga terbukti dapat menghambat pertumbuhan $C$. albicans pada konsentrasi 1000 ppm dengan zona hambat sebesar 8,12 $\mathrm{mm}$. Konsentrasi hambat tumbuh minimum

\section{Daftar Pustaka}

Adegoke, A.A. dan A. Bukola. (2009). Antibacterial activity and phytochemical analysis of leaf extracts of Lasienthera africanum. African Journal of Biotechnology, Vol 3, No 3 hal. 156.

Djunaedy, A. (2008). Aplikasi Fungisida Sistemik dan Pemanfaatan Mikoriza dalam Rangka Pengendalian Patogen Tular Tanah pada Tanaman Kedelai (Glycine max L.). Embryo, Vol. 5. No. 2, Hal. 1-9.

Fitriani, A, A. Aryani, H. Yusuf \& Y. Permatasari. (2012). The Exploration of Ketosynthase Gene on Endophytic Bacterial Root of Vetiveria zizanioides L. International Journal of Basic \& Applied Sciences, Vol.13, No.04, Hal. 112-119.

Harborne, J.B. (1987). Metode Fitokimia : Penuntun Cara Modern Menganalisis Tumbuhan Edisi Kedua. Bandung: ITB.

Ismail, A., Marjan, Z., Foong, C. (2004). Total Antioxidant Activity and Phenolic Content in Selected Vegetables. Food Chemistry. Vol.87, No.1, Hal. 581-586.

Jawetz, Melnick, Adelberg. (2005). Mikrobiologi Kedokteran. Edisi I: 352-358. Jakarta: Salemba Medika.

Mustikasari, K \& Ariyani, D. (2010). Skrining fitokimia ekstrak metanol biji Kalangkala (Litsea angulata). Sains dan Terapan Kimia. Vol.4, No.2, Hal.131-136.

Sabir, A. (2005). Aktivitas antibakteri flavonoid propolis Trigona sp. terhadap bakteri Streptococcus
(KHTM) ekstrak metanol daun mangga terhadap $C$. albicans yaitu pada konsentrasi 65 ppm dengan zona hambat $0,64 \mathrm{~mm}$. Golongan senyawa metabolit sekunder yang terdapat dalam ekstrak metanol daun mangga berdasarkan uji warna yaitu senyawa alkaloid, flavonoid, stereoid, polifenol, tanin, dan saponin

Ningsih, Dian. R, Zusfahair, Purwati. (2014). Potensi Ekstrak Daun Kamboja (Plumeria Alba L.) Sebagai Antibakteri Dan Identifikasi Golongan Senyawa Bioaktifnya. Jurnal Molekul. Vol.9, No.2, Hal. 101-109.

Ningsih, D. R., Zusfahair, Kartika D. (2016). Identifikasi Senyawa Metabolit Sekunder Serta Uji Aktivitas Ekstrak Daun Sirsak Sebagai Antibakteri. Jurnal Molekul. Vol. 11 No. 1 Hal. 101-111.

Nobre, C., Moura, F. (2005). Standardization of Extracts from Momordica Charantia L. (Cucurbitaceae) by Total Flavonoids Content Determination. Actafarm Bonaerense. Vol. 24, No.1, Hal. 562566.

Nychas, G. J. E. dan C. C. Tassou. (2000). Traditional Preservatives-Oil and Spices. London: Academic Press.

Pelczar, M.J. dan Chan, E.C.S. (1988). Dasar-dasar Mikrobiologi. Jilid 2. Penerjemah Ratna Siri hadioetomo. Jakarta: Universitas Indonesia Press.

Pohan, A., Purwaningsih, E., Dwijayanti, A. (2013). Efek Kelasi Ekstrak Etanol Daun Mangifera foetida pada Feritin Serum Penderita Talesemia di RS Cipto Mangunkusumo, J.I. Med Assoc., Vol. 1, No.1, Hal. 45-52.

mutans (in vitro). Jurnal Kedokteran Gigi. Vol.38, No.3, Hal. 135-141, 
Sari, N. (2010). Daya Antibakteri Estrak Tumbuhan Majapahit (Crescentia cujete L.) terhadap Bakteri Aeromonas hydrophila. Laporan Penelitian. Surabaya: Institut Teknologi Sepuluh November.

Widijanti, A., dan T.R Bernard. (2007). Pemeriksaan Penderita Laboratorium Diabetes Melitus.
Laboratorium Patologi klinik RSUD Dr. Saiful Anwar. http://www.tempo.co.id/medika/onlin e/tmp.online.old/pus-1.htm. diakses tanggal 08 Desember 2015.

Zhu Y., Qi X.Z., Zhong J.J. (2000). Epoxide Sesquiterpenes and Steroid From Cremathodium discoideum, Australian Journal of Chemistry, Vol.53, No.10, Hal. 831-834. 